\title{
TREADING FINE LINES $^{1}$
}

\author{
Cynthia Hardy \\ Department of Management \& Marketing \\ University of Melbourne \\ 198 Berkeley Street \\ Parkville, Victoria 3010 \\ Australia \\ chardy@unimelb.edu.au
}

${ }^{1}$ I would like to thank Robyn Thomas for her thoughtful and helpful comments on earlier versions of this paper. 


\begin{abstract}
This paper reflects on the different ways in which the concept of power is treated in elite US compared to European journals. Some observers have argued that critical researchers should not bother to try and publish their work in elite US journals because of the compromises that have to be made in doing so. This essay argues that a "limited engagement" with these journals constitutes one way of trying to resist the power/knowledge relations that are so deeply embedded in them.
\end{abstract}


One of the most intriguing and challenging topics in the study of organizations is the notion of power. Everyone knows that power is important (although many are uncomfortable about admitting it); everyone knows organizations “work” on power; and everyone is personally concerned with how power in her or his own organization will affect them personally. And yet power remains an enigma -at least partly due to the very different ways in which the concept is treated in US and European journals.

In Europe, diverse critical researchers from organizational studies, labour process theory and industrial relations introduced the study of power as domination into organizational research in the 1970s. In the 1980s and 1990's these ideas were developed further with the even more profoundly radical re-conceptualization of power inspired by Foucault and other "postmodern” thinkers. Consequently, critical European journals located at the "periphery" of the field (Grey, 2010), are more likely to publish research that explores the multiple layers of power that reside in ostensibly neutral structures, cultures and knowledge, as well as studies of domination, surveillance and resistance. These subjects are rarely tackled in the centrally located "elite” US journals, such as the Academy of Management Review, the Academy of Management Journal and Administrative Science Quarterly, which are more likely to adopt a narrow conceptualization that equates power with resource dependencies and to take a managerialist or functionalist stance that depoliticizes the use of power by managers. These differences reflect broader variations in that European organizational research is more likely to be interpretive, constructionist and qualitative and to incorporate the work of the "great thinkers” or philosophers, while the elite US journals are more likely to emphasize methodological rigour and to be more closely aligned with approaches modelled after the natural sciences (Meyer \& Boxenbaum, 2010).

Writing about power - or, to be more accurate, publishing articles on power - in the elite US journals is therefore fraught with obstacles for non-mainstream scholars. Some 
European critical researchers have argued that we should not even bother to try because of the compromises that have to be made in doing so.

The investigation of power has been a regular theme in my own research over the last three decades. It started with my PhD, where I used Lukes' (1974) three dimensional view of power to study organizational closure. Later on, I adopted the lens of organizational discourse theory to examine power in a variety of other organizational contexts, drawing on the work of theorists such as Foucault and Fairclough $(1992,1995)$. My career thus loosely follows the broader “European” research trajectory, but I have nonetheless published a number of works in the U.S. journals despite the difficulties of convincing reviewers to see the organizational world in unaccustomed terms. I believe that, while there are risks, there is merit in targeting elite US journals with empirical studies in which complex theorizing is brought to bear on some of the intractable problems that face contemporary organizations. Such a move of "limited engagement" with a fairly entrenched system constitutes one way of trying to resist the power/knowledge relations that are so firmly embedded in these journals. Of course, the non-engagement strategy proposed by other writers is, in its own right, a form of resistance. However, it is not free from its own power/knowledge dynamics and there are political costs to those who adopt this strategy.

\section{FOUCAULT, ORGANIZATIONAL RESEARCH AND ME}

The late 1980s and early 1990s were a heady time in the organization and management theory in Europe and, especially, the UK as postmodern ideas started to infiltrate critical studies of management. Burrell and Morgan had written Sociological Paradigms and Organizational Analysis in 1979, which mapped out four research approaches related to underlying assumptions concerning the nature of our world and the nature of knowledge. While this framework did not identify postmodernism as an explicit research domain, the demarcation of territories outside the dominant orthodoxy of functionalism 
sparked interest in new ways of doing research. During the following decade, a more explicit postmodern approach was developed, initially as writers such as Gibson Burrell, Stewart Clegg, and David Knights started to translate the ideas of (mainly) French philosophers for organizational researchers. In the 1990s, organizational theorists both sides of the Atlantic were experimenting with new ways of writing up their own work, as well as subjecting mainstream work to profound scrutiny; while journals - such as this one and Organization were set up with more innovative mandates than their older, more staid counterparts to celebrate these new developments.

At the time, I was viewing these developments from some distance - physically and intellectually. I had moved to McGill University from the UK in 1981 and temporarily diverted my attention to studies of university strategy making. But I was eventually - and emphatically - drawn to the power of a postmodern persuasion as a result of a new research study that simply could not be forced into traditional conceptions of power; not even a multifaceted Lukesian framework. The study in question was a comparison of refugee determination systems in the UK, Canada and Denmark. The 1948 United Nations (UN) Universal Declaration of Human Rights asserts that everyone has the right to seek asylum from persecution. Refugees are persons who "owing to a well founded fear of being persecuted for reasons of race, religion, nationality, membership of a particular social group or political opinion, is outside the country of his/her nationality and is unable, or owing to such fear, is unwilling to avail himself/herself of the protection of that country.” Asylumseekers are those who, having escaped from their original country seek refuge in another country; and refugee determination systems are the processes to which they must submit if they are to be "found" to be refugees.

As soon as I started the study, it was clear that conventional theories of power - as a resource wielded by actors with free agency - were not going to work. In fact, not even the 
more sophisticated view of power provided by Lukes did justice to this complex situation. Despite governments having a very clear agenda of controlling the production of refugees, particularly those that reach their borders to claim asylum; and despite possessing considerably more power than the NGOs that represent refugees, let alone refugees themselves, these sovereign entities could not - and cannot - control refugee outcomes. The international flow of asylum-seekers is, quite simply beyond the ability of any single government to manage: there are over 15 million refugees world-wide as a result of events in distant countries, such as war, famine and political upheaval. Even the tiny proportion of refugees who seek asylum in developed countries cause great consternation to governments. Capricious media coverage, emotive discourses of terrorism, border protection and racism, and unpredictable legal decisions can suddenly change conditions for governments, as much as for asylum-seekers.

Foucault's repudiation of sovereign power seemed tailor-made for the study of refugees - then and now. Power is very much a web, Foucault argues, in which everyone is trapped - governments as much as refugees, albeit with very different results. Refugee determination systems are, in Foucault's terms, regimes of truth - classifying and producing certain kinds of individual on the basis of certain kinds of truth. These classifications have significant effects, such as whether an individual is found to be a refugee (and being able to stay in the country and ultimately secure citizenship) or not (and not being admitted entry or being deported). This form of power is not only repressive but also productive - in the sense that it produces particular kinds of identities that shape how people are known, what they experience, and how they act. It is impossible to escape this web of power; nor can it be eradicated, but it can sometimes be harnessed it to produce different effects. So, when individuals resist this system: they do so by working through it, rather than against it. In other words, trying to make sense of the complexity of refugee determination, let alone to reflect 
on the problems that it throws up, require a sophisticated conceptualization of power that only approaches like Foucault’s can provide.

\section{FOUCAULT AND THE ELITE US JOURNALS}

I was unsuccessful at publishing this Foucauldian approach to refugee determination systems in the elite US journals in the 1990s. Luckily, other writers were more effective at bringing Foucauldian understandings to a US audience (e.g., Boje, 1995; Calás \& Smircich, 1999; Covaleski, Dirsmith, Heian \& Saja, 1998; Knights, 1992; Townley, 1993). This work provided sound bedrock for my own research which, in the last decade or so - and with the help of invaluable and insightful colleagues - has been published in the top US journals. Does this perhaps mean that the elite US publishing scene has changed and is more receptive to such work? Well, not really.

Over the last 10 years, only two articles in Administrative Science Quarterly (ASQ) cite Foucault, according to Ebsco's Business Source Complete. In the Academy of Management Journal (AMJ) the number is 9, although the vast majority of these articles mention the name only in passing. In the Academy of Management Review (AMR) a dozen or so papers over the last ten years make more than a passing reference to his work, although nearly all involve authors working at universities outside the USA. Papers on power in these journals - which are few and far between - nearly always adopt a mainstream conceptualization of power as the use of financial and symbolic resources by actors to influence the behaviour of others. In doing so, they view power dynamics as some kind of conscious strategy between protagonists who are fully aware of the political issues and who are able to exercise full agency in utilizing the power resources at their disposal in event of conflict.

This conceptualization of power has moved little beyond the work of the 1960s and 1970s based on resource dependencies (e.g., Mechanic, 1962; Pfeffer \& Salancik, 1974). The 
profound and radical conceptual developments of the last 40 years are rarely mentioned, leaving the so-called elite US journals significantly - and inexcusably - behind the times. It seems that just as the concept of power was being opened up and taken apart in Europe; it was being closed down in these elite journals. While a narrow conceptualization makes it easy to study a variable involving some measurement of resource dependencies that might be named “power”, it makes it almost impossible to explore how power is embedded in the fabric of organizational structures and processes, the ways in which power is used unobtrusively to secure cooperation, the constraints on agency afforded by pervasive but largely invisible disciplinary processes to which everyone is subjected, or the inextricable links between power and knowledge.

An unwillingness (whether intentional or unintentional) to enlist in more complex theorizing is problematic given that an understanding of power would seem to be essential in dealing with the intractable problems in contemporary society. However, it seems that the elite US journals are not interested in complex conceptualizations of power, despite its relevance to American society. For example, Barley (2007) has complained about the silence of organizational researchers in relation to power despite the inordinate political power currently wielded by US corporations. Even more worry is the lack of interest of elite US journals in contemporary problems more generally. It was the irresolvable problem of refugees that drew me to a postmodern conceptualization of power; and we face numerous other challenging issues worth trying to understand in more depth - climate change, the global financial crisis, and intransigent inequities of varying kinds, to name but a few. However, an Ebsco search found no articles with global warming/climate change or global financial crisis in the abstract in $A S Q, A M J$ and $A M R$, suggesting these important issues rarely attract the attention of these journals. Small wonder, then, that despite the concerns expressed of many former editors (e.g., Barley, 2007; Rynes, Bartunek \& Daft, 2001), 
publishing in the so-called "high impact" elite journals remains "virtually tantamount to having low or no impact on anyone outside academia (Gabriel, 2010: 768).

If these former editors of US elite journals are serious about becoming more relevant then we need more papers that both engage in complex theorizing and examine important issues through rich empirical research. Unfortunately, if there has been a disregard for the theorizing part of the equation, there appears to have been outright disdain for empirical articles. The majority of the papers published in the elite journals in the 1990s mentioning Foucault were theoretical - not empirical. Perhaps this was to be expected as scholars initially wrestled with the implications of Foucault's insights for organizations, as well as postmodernism more generally. Having now worked through many theoretical questions, one might imagine that more papers would have since been published in which theoretical developments are elaborated in empirical settings. But, the publication trend in the last decade still indicates many more papers on Foucault in $A M R$ than in $A M J$; and, when North American scholars do pick up on European ideas, they are more likely to cite theory articles than empirical ones (Battilana et al., 2010).

\section{A FINE LINE OR A BRIDGE TOO FAR?}

If the elite US journals are unwelcoming of such work on power and critique; there is scepticism among critical researchers of work that is targeted at them. These researchers are with justification - worried that publishing in elite US journals leads to the "domestication" of the complex and nuanced work of people like Foucault, stripping "critical thinking of some of its more provocative and original insights” (Cooper, Ezzamel \& Willmott, 2008: 690), especially given that the mantra of methodological "rigor" carries with it "a baggage of positivist notions of validity” (Grey, 2010: 687).

My view, however, is somewhat different. I believe that it is important that, without fetishizing them (Willmott, 2011), some researchers might sometimes target elite US journals 
with a view to publishing empirical studies where complex theorizing is brought to bear on some of the intractable problems that face contemporary organizations. Yes, there are risks. Critique will be softened, perhaps even blunted. Compromises will be made. Complex ideas may have to be streamlined. Concepts will be taken up by others and bent out of (sometimes) recognizable shape in subsequent publications. But, some ideas will persist, building on the earlier work that has sought to introduce more complex thinking into these journals. In this way, it is possible to build traces of an alternative voice within the system that may continue to endure. It won’t overturn the system nor will it magically propel the critical periphery to the centre of the field: it is but one small way to resist and, if successful, it creates a slightly bigger space - albeit incrementally - for critique.

The alternative - having critical theorists simply turn their back on the elite US journals - is not going to open up space for critical work in the centre of the field either. Moreover, it is an option that is far more accessible - and less costly - to senior professors at the top of the academic food chain, looking out from behind the vantage point of tenure, reputation and mobility. Such commentators have lambasted other researchers for thinking publishing is a game. I would argue it is a game - a Wittgensteinian language game with some very tricky rules. It is also part of our job. We have to publish somewhere. This should not preclude critical journals like this one, or monographs and book chapters. But nor should it preclude US elite journals. The strictures of journal lists and research assessment audits are, indeed, bearing down on our discipline, particularly on early career researchers. In my university, it does make a difference to promotion and tenure if one has an elite publication. Why should early career researchers bear the costs of eschewing these journals? To ignore the pressures they face or to dismiss these researchers as narcissistic and career hungry (Alvesson, 2013) hardly provides the ethics of care that the discipline needs (Gabriel, 2010). On the other hand, considered and constructive - and yes, critical - appreciation about how 
such individuals might both work within and also resist the system might go some way towards doing so.

Of course, any paper sent to an elite US journal will, if it is published, be shaped by the institutional practices to which it has been subjected. But so, too, are those published in European or critical journals. Don’t let us kid ourselves that somehow the critical space is more pure and unadulterated than other spaces. It is equally subject to politics, fads, fashions, and gate keeping by those defending their prestige knowledge patch. As Foucault always made clear - power and knowledge are inseparable.

In sum, targeting the journals at the centre of our field with papers that combine complex, critical theorizing with insightful and relevant empirical studies is one way to enrich the knowledge produced in our field. For critical researchers, it requires treading a fine line. The effects may be incremental and are not without risk, but without some people pushing from the periphery, nothing will change. And I do see signs of change at the centre some of the papers I have reviewed recently for $A M J$ involve rich qualitative studies of complex issues and, while they may not always be critical, they nonetheless have involved complex theorizing that adds important insights to our understanding of these issues. Moreover, handling editors and reviewers have been generally supportive - helping authors revise these complicated papers with a view to honing the theoretical contribution and improving the readability of the paper, without positivistic posturing or condemnatory censorship. Gatekeepers may exclude and enervate, but they can also encourage and enhance.

At the same time, we must not forget the importance of the periphery - the immense value of journals like this one, as well as those in Europe and elsewhere. These are the spaces where complex, novel and radical ideas are first aired, and where theoretical momentum is built up that may, at some point, infiltrate the centre. You can’t have a centre without a periphery and, as even mainstream researchers have noted, institutions do change because of 
what goes on at the fringe (e.g., Leblebici, 1991). Treading the fine line between centre and

fringe provides one path toward greater academic inclusiveness, progress and relevance.

\section{REFERENCES}

Alvesson, M. (2013). Do we have something to say? From re-search to roi-search and back again. Organization, 20: 79-90.

Alvesson, M., \& Willmott, H. (1992). On the idea of emancipation in management and organization studies. Academy of Management Review, 17(3): 432-464.

Barley, S.R. (2007). Corporations, democracy, and the public good. Journal of Management Inquiry, 16(3): 201-215.

Battilana, J., Anteby, N., \& Sengul, M. (2010). The circulation of ideas across academic communities: When locals re-import exported ideas. Organization Studies, 31(6): 695713.

Boje, D. (1995). Stories of the storytelling organization: A postmodern analysis of disney as 'Tamara-land.' Academy of Management Journal, 38(4): 997-1035.

Burrell, G., \& Morgan, G. (1979). Sociological paradigms and organisational analysis: elements of the sociology of corporate life. London: Heinemann.

Calás, M.B., \& Smircich, L. (1999). Past postmodernism? reflections and tentative directions. Academy of Management Review. 24(4): 649-671.

Cooper, D.J., Ezzamel, M., \& Willmott, H. (2008). Examining institutionalization: A critical theoretic perspective. In R. Greenwood, C. Oliver, R Suddaby \& K. Sahlin (Eds.) Handbook of organizational institutionalism (673-701). London: Sage.

Covaleski, M. A., Dirsmith, M. W., Heian, J. B., \& Samuel, S. (1998). The calculated and the avowed: Techniques of discipline and struggles over identity in Big Six public accounting firms. Administrative Science Quarterly, 43: 293-327

Gabriel, Y. (2010). Organization studies: A space for ideas, identities and agonies. Organization Studies, 31: 757-775.

Grey, C. (2010). Organization studies: Publications, politics and polemic. Organization Studies, 31: 677-694.

Knights, D. (1992). Changing spaces: the disruptive impact of a new epistemological location for the study of management. Academy of Management Review, 17(3): 514-536.

Leblebici, H., Salancik, G. R., Copay, A., \& King, T. (1991). Institutional change and the transformation of interorganizational fields: An organizational history of the U.S. radio broadcasting industry. Administrative Science Quarterly, 36: 333-363.

Lukes, S. (1974). Power: A radical view. London: Macmillan.

Mechanic, D. (1962). Sources of power of lower participants in complex organizations. Administrative Science Quarterly, 7(3), 349-64.

Meyer, R.E., \& Boxenbaum, E. (2010). Exploring European-ness in organization research. Organization Studies, 31(6): 737-755

Pfeffer, J., \& Salancik. G. (1974). Organizational decision making as a political process. Administrative Science Quarterly, 19: 135-51.

Rynes, Sara L., Bartunek, J.M., \& Daft, R. L. (2001). Across the great divide: Knowledge creation and transfer between practitioners and academics. Academy of Management Journal, 44: 340-355.

Townley, B. (1993). Foucault, power/Knowledge and its relevance for human resource management. Academy of Management Review, 18(3): 518-545.

Willmott, H. (2011). Journal list fetishism and the perversion of scholarship: reactivity and the ABS list. Organization, 18(4): 429-442. 


\section{University Library}

\section{- M M N E R VA A gateway to Melbourne's research publications}

Minerva Access is the Institutional Repository of The University of Melbourne

Author/s:

Hardy, C

Title:

Treading fine lines

Date:

2013

Citation:

Hardy, C. (2013). Treading fine lines. Journal of Management Inquiry, 22 (4), pp.451-456. https://doi.org/10.1177/1056492613481170.

Persistent Link:

http://hdl.handle.net/11343/116059 